\title{
Cultural Value And Travel Motivation Of European Tourists
}

Acheraporn Plangmarn, Ramkhamhaeng University, Thailand Bahaudin G. Mujtaba, Nova Southeastern University, USA

Mohamed Pirani, Liverpool John Moores University, UK

\begin{abstract}
The purpose of this study was to investigate the relationship among demographic characteristic, cultural values, and travel motivations in regards to understanding the context of tourist's motivation and how cultural values impact the travel motivation. The study was limited to the tourists who came to the attractive city of Chiang Mai during the research time period. The results indicated that demographic characteristic is a source of cultural values and cultural values impact the travel motivations of the tourists. Also, no significant relationship was found between demographic characteristic and travel motivations. Data analysis and implications are discussed and recommendations are provided.
\end{abstract}

Keywords: Cultural Value and Travel Motivation of European Tourists

\section{INTRODUCTION}

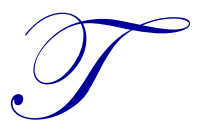

ourism is one of the world's largest multinational economic activities (Friedman, 1995); it ranks among the top five export industries for $83 \%$ of countries (Fayed \& Fletcher, 2002). In a globalized world, hotels, restaurants, and travel organizations will hire more workers and serve more customers from diverse cultural backgrounds. Understanding those who are culturally different will present a global challenge to the tourism and hospitality organizations that compete in a global marketplace.

Cultural variations in value orientations and social behavior have directly impacts on tourist holiday experiences. The hosts' ability to respond effectively to a culturally different tourist is an important element determining positive tourist holiday experiences and satisfaction. Consumer behavior and travel and tourism marketing researchers devote considerable attention to understanding the nature of travel choice, experience and destination as well as the relationship among culture, subculture and consumer behavior has also started to draw attention (Engel and Blackwell, 1982). For example, the work of Woodside et al. (2007) extends and applies ecological systems theory using a narrative case study method to examine consumer leisure and travel behavior. Cultural diversity has different meanings and interpretations because culture is differently defined by various nations and ethnic groups. The modern anthropological definition of culture refers to common knowledge, perceptions, and values that constitute the foundation of social, economic, and religious institutions in a society (Svanberg \& Runblom, 1988).

With the trend of globalization, growth of transnational corporations, and the emergence of culture related issues, cultural difference reveals its significance in terms of explaining the behavior of consumers and designing efficient marketing strategies and tools (Keegan, 1984; Usinier, 1993; Weiermair, 2000).

Considering human, the indication would be that research into why people travel and into what they intend to do on holidays, would generate a multiplicity of motives related to the tourist destinations.

Motivations are forces that influence and predispose to a specific behavior (Dann, 1981; Pearce, 1982). In tourism research, a perception is the image of a tourist destination that makes effective the behavior intentions (Gnoth, 1997). Baloglu and McCleary (1999) state that perceptions about the destination are a function of internal 
motivations (push motives) and external motivations (pull motives). Each tourist has his/her own internal and external motivations to travel which lead to different perceptions about a tourist destination.

\section{LITERATURE REVIEW}

\section{Culture}

The definitions of culture that were presented cover a very wide range of meanings. However, they do not exhaust the many uses of the term culture. In 1952, Alfred Kroeber and Clyde Kluckhohn compiled a list of 164 definitions of culture. As a conclusion of their extensive analysis, they suggested a comprehensive and all-inclusive definition of culture: "Culture consists of patterns, explicit and implicit, of and for behavior acquired and transmitted by symbols, constituting the distinctive achievements of human groups, including their embodiments in artifacts; the essential core of culture consists of traditional (i.e., historically derived and selected) ideas and especially their attached values; culture systems may, on the one hand, be considered as products of action, on the other as conditioning elements of further action"' (Kroeber \& Kluckhohn, 1952, p. 181). This definition is consistent with Malinowski's (1988, p. 74) more concise definition of culture as "the sum of goods, of rights and duties, of ideas, beliefs, capabilities, and customs." Culture, as these definitions suggest, represents a system of tangible and intangible components. Tangible components of culture represent material culture and comprise productive forces and physical elements necessary to support human life, such as clothing, tools, food, buildings, paintings, and many other cultural objects and artifacts. Intangible elements of culture represent non-material culture and refer to values, beliefs, attitudes, morality, ethics, spirituality, traditions, and customs.

\section{Culture values}

Cultural values is an umbrella concept that includes such elements as shared values, beliefs and norms that collectively distinguish a particular group of people from others (Pizam et al., 1997). These widely shared values are programmed into individuals in subtle ways from quite an early age (Otaki et al., 1986), are resistant to change (Hofstede, 1991) and remain evident when at home or while traveling abroad (Pizam and Reichel, 1996; Pizam and Sussmann, 1995).

Cultural values are shared, abstract ideas about what a social collectivity views as good, right and desirable (Williams, 1970). Cultural values are the broad goals that members of the collectivity are encouraged to pursue; they serve to justify actions taken in pursuit of these goals (Schwartz, 1999). Widely shared norms, practices, symbols and rituals express underlying cultural values (Sagiv and Schwartz, 2000; Trice and Beyer, 1993). Consequently, cultural values play a crucial role in the way social institutions function. Studies of cultural values have focused most extensively on nations (Hofstede, 2001; Inglehart, 1997; Schwartz, 2004). Here we focus on the cultural values of business organizations.

\section{Cultural Value Dimension}

Schwartz (1994, p. 88) defined human values as "desirable goals, varying in importance, that serve as guiding principles in people's lives" consistent with definitions suggested by Kluckhohn (1951) and Rokeach (1973). Schwartz values are based on needs derived from:

- Individuals' requirements as biological organisms.

- $\quad$ Society's requirement for coordinated social interaction.

- Groups' requirement for survival and support (Schwartz, 1992).

Schwartz's value types were derived from a set of items "developed to measure the content of individual values recognized across cultures" (Schwartz, 1994, p. 88). Schwartz claimed that the items were close to an exhaustive set of etic cultural dimensions and that Hofstede's four dimensions were included within these dimensions (Schwartz, 1994). A total of 56 values items were developed and distributed to 87 teacher and student samples from 41 cultural groups in 38 nations between 1988 and 1992. Respondents were asked to rate the importance each value served as a guiding principle in their lives. Since, individual values reflect an individuals' 
unique experience (individual level value), as well as normative cultural influence (cultural level value), they can be analysed at individual and cultural levels (Schwartz, 1994). At an individual level, sets of value priorities are said to reveal the trade-offs an individual makes in order to pursue a particular value. That is, respondents emphasize important values, while downplaying less important or opposing values. Using a two-dimensional smallest space analysis, Schwartz (1992) found individual level values are organized along two basic dimensions, which he termed conservation to openness to change and self-transcendence to self-enhancement. Within these two dimensions, ten individual values dimensions were identified that represented likely conflicts and compatibility between values. These individual level value types are described below (Schwartz and Bardi, 2001, p. 270):

1. Power. Social status and prestige, control or dominance over people and resources.

2. Achievement. Personal success through demonstrating competence According to social standards.

3. Hedonism. Pleasure and sensuous gratification for oneself.

4. Stimulation. Excitement, novelty, and challenge in life.

5. Self-direction. Independent thought and action - choosing, creating, exploring.

6. Universalism. Understanding, appreciation, tolerance, and protection for the welfare of all people and for nature.

7. Benevolence. Preservation and enhancement of the welfare of people with whom one is in frequent personal contact.

8. Tradition. Respect for, commitment to, and acceptance of the customs and ideas that traditional culture or religion impose on the self.

9. Conformity. Restraint of actions, inclinations, impulses likely to upset or harm others and to violate social expectations or norms.

10. Security. Safety, harmony, and stability of society, of relationships, and Of self.

\section{Travel motivation}

Travel motivation refers to a set of needs that cause a person to participate in a tourist activity (Pizam, Neumann, \& Reichel, 1979). According to Cropmton (1979) most tourist motivation related to travelers' decision making in choosing a destination involves the concept of push and pull factors. Tourists are pushed and pulled by some sources of inherent forces. These forces explain how individuals are pushed by internal variables, and how they are pulled by a travel destination (Uysal \& Hagan, 1993). The push factors are socio-psychological motives such as the desire for escape, novelty seeking, adventure seeking, dream fulfillment, rest and relaxation, health and fitness, prestige, and socialization. Most push factors originate from intangible or intrinsic desires of human beings (Uysal \& Jurowski, 1993). The pull factors are motives aroused by the destination rather than emerging exclusively from within the travelers themselves. Pull factors include tangible and intangible cues of a specific destination that pull people to realize the needs of particular travel experiences, such as natural and historic attractions, food, people, recreation facilities, and marketed image of the destination (Uysal \& Hagan, 1993). The push motivations have been thought useful for explaining the desire to go on a vacation while pull motivations have been thought useful for explaining the choice of destination. Fodness (1994) argues that motivation theories describe a dynamic process of internal psychological factors (needs, desires and goals) which generate a level of tension in an individual and influence him or her towards purchase. Baloglu (1997), Dann (1996) and Gartner (1993) suggest that motivations have a direct influence on the affective component of an image such as a destination that generates certain feelings. Individuals with different motivations may similarly evaluate a tourist destination if the destination is able to succeed in the desired benefits.

"Motivation is the need that drives an individual to act in a certain way to achieve the desired satisfaction" (Beerli and Martı'n, 2004, p. 626). Many different reasons and motives compel people to travel. These forces are perceived as being able to decrease the condition of tension felt by the individual. The state of tension then gives way to the necessity that encourages an action or attitude (Fodness, 1994). Although the decision to satisfy needs may rely on other psychological variables, in reality, all human behavior is motivated (Crompton, 1979). 


\section{Dimensions of Travel Motivations}

Two important concepts in analyzing travel motivations are push and pull factors. Pull factor are the external forces of the destination attributes which are thought to account for actual destination choice, while push factors are people's own internal forces that explain their desire to go on a vacation (Bello \& Etzel, 1985). The push factors are socio-psychological motives such as the desire for escape, novelty seeking, adventure seeking, dream fulfillment, rest and relaxation, health and fitness, prestige, and socialization. Most push factors originate from intangible or intrinsic desires of human beings (Uysal \& Jurowski, 1993). The pull factors are motives aroused by the destination rather than emerging exclusively from within the travelers themselves. Pull factors include tangible and intangible cues of a specific destination that pull people to realize the needs of particular travel experiences, such as natural and historic attractions, food, people, recreation facilities, and marketed image of the destination (Uysal \& Hagan, 1993). The push motivations have been thought useful for explaining the desire to go on a vacation while pull motivations have been thought useful for explaining the choice of destination.

Crompton's (1979) widely accepted push-pull model represent two forces in tourism research. Push motivations correspond to forces whereby individuals are pushed by motivational factors into making travel decisions and seen as the desire for personal achievement, satisfaction, rest and relaxation, adventure, knowledge, getting away, and social interaction. Pull motivations, on the other hand, reflect internal or emotional factors prompted by the attributes of a destination (Uysal et al., 1996). The characteristics or attributes of a destination allow the tourist to create expectations in terms of satisfying motivational needs. Several studies have explored motivational determinants in the tourism context (Beerli and Martı'n, 2004; Correia and Crouch, 2004; Correia et al., 2007b; Crompton, 1979; Dann, 1981; Fodness, 1994; Gnoth, 1997; Iso-Ahola and Mannel, 1987; Lundberg, 1990; Mohsin and Ryan, 2003; Pearce, 1982; Shoemaker, 1989; Uysal and Hagan, 1993; Uysal et al., 1996; Yoon and Uysal, 2005).

\section{RESEARCH METHODOLOGY}

A survey was developed in order to test the proposed research questions. The survey includes three sections: the first section tries to measure the personal basic information of the samples. The second section presents the cultural values of the samples. The last section considers the travel motivation of the samples.

Among 428 copies of questionnaires was distributed to the tourists, 249 were retrieved. The return rate is 58.18 percent and there were 22 surveys received after the cut-off date. The prescreening resulted in 27 surveys being dropped. The total number of useable surveys entered into the database was 200 . The useable surveys were separated into the group following an ethic. There are three groups were exceeded 30 subjects; thus, the sampling distributions were expected to be approximately normal. The three study groups were French, Spanish and German.

This research examined the relationship among demographic characteristic, cultural values as independent variables and travel motivations as dependent variables. The following 6 research questions were proposed:

1. How difference and similarity of the patterns of cultural value of each of the three nation.

2. What difference and similarity pattern of travel motivation of the three nations.

3. Does nationality have any significant impact on the cultural values and travel motivations.

4. How cultural value influence travel motivation.

5. Does demographic influence cultural value.

6. Does the third-variable that influenced the correlated variable of the

Cultural values and travel motivations which were gender, age, status, and education of the tourists?

\section{STATISTICAL DATA ANALYSIS}

\section{Analysis of basic information}

The result of the investigation reveals that most (55.6 percent) of the French tourists who receive the questionnaire are males; 72.2 percent of French tourists are 24-35 year-old; 44.4 percent of French tourist are 
partners and 66.7 percent of French tourists education are Master Degree. Most of the Spanish tourists who receive the questionnaire are males (53.3 percent); 73.3 percent of Spanish tourists are 24-35 year-old; 36.7 percent of Spanish tourist are partners and 60 percent of Spanish tourists education are Master Degree. Most of the German tourists who receive the questionnaire are males (55.7 percent); 62.5 percent of Spanish tourists are 24-35 year-old; 67.5 percent of Spanish tourist are partners and 50 percent of Spanish tourists education are Master Degree.

\section{Principal component analysis}

Cultural values and travel motivations. The reduction of the initial 10 cultural values into eight factors, the initial 2 travel motivation into 2 factors together accounting for 57.27 percent of the total variance $(\mathrm{KMO}=0.84$; Bartlett test: $p=0.00$ ), was obtained through PCA. These finding are presented in Table 1. Considering the meaning of the cultural values with higher loadings, the cultural values were labeled cultural values and the travel motivations were labeled travel motivations. The internal consistency and reliability of these factors was measured by the corresponding Cronbach's $\alpha$ coefficients which $.7-.8$ is acceptable value for Cronbach's coefficient alpha (Kline 1999). The Cronbach's alphas for both cultural values and travel motivation were .886 and .749 respectively. The mean importance level of each cultural value and travel motivation was based on the mean scores.

Table 1 - Rotated Component Matrix of Cultural Values and Travel Motivation

\begin{tabular}{|c|c|c|c|c|}
\hline Questionnaire Items & $\begin{array}{c}\text { Factor } \\
\text { Loadings }\end{array}$ & $\begin{array}{l}\text { Eigen } \\
\text { value }\end{array}$ & $\begin{array}{c}\text { Variance } \\
\text { Explained }\end{array}$ & $\begin{array}{l}\text { Cronbach's } \\
\text { Alpha }\end{array}$ \\
\hline Cultural Values & & 4.59 & $38.22 \%$ & .89 \\
\hline Benevolence & .80 & & & \\
\hline Self-Direction & .80 & & & \\
\hline Universalism & .77 & & & \\
\hline Security & .76 & & & \\
\hline Conformity & .74 & & & \\
\hline Achieve & .72 & & & \\
\hline Tradition & .62 & & & \\
\hline Stimulation & .58 & & & \\
\hline Travel Motivations & & 2.29 & $19.05 \%$ & .75 \\
\hline Pull & .86 & & & \\
\hline Push & .86 & & & \\
\hline Total variance explained & & & $57.27 \%$ & \\
\hline
\end{tabular}

\section{Patters of Cultural Values}

The results of the One-Way ANOVA in terms of patterns of cultural values, found between the French, Spanish and German tourists of the study, are summarized in Table 2. Difference patterns are indicated by a ' $\mathrm{O}$ ' and, while similarity pattern are indicated by $\sqrt{ }$

Table 2 - Patterns of Cultural Value of the Tourists by Nationalities

\begin{tabular}{lccc}
\hline \multicolumn{1}{c}{ Cultural Value } & French & Spanish & German \\
\hline Power & $\sqrt{ }$ & $\sqrt{ }$ & $\sqrt{ }$ \\
Achievement & $\sqrt{ }$ & $\sqrt{ }$ & $\sqrt{ }$ \\
Hedonism & $\sqrt{ }$ & $\sqrt{ }$ & $\sqrt{ }$ \\
Stimulation & $\sqrt{ }$ & $\sqrt{ }$ & O \\
Self-Direction & O & $\sqrt{ }$ & O \\
Universalism & O & $\sqrt{ }$ & O \\
Benevolence & O & $\sqrt{ }$ & $\sqrt{ }$ \\
Tradition & $\sqrt{ }$ & O & O \\
Conformity & O & O & O \\
Security & O & & \\
\hline
\end{tabular}

Notes. $\sqrt{ }$ indicates a similarity pattern to other groups while $\mathrm{O}$ indicates a difference pattern to the group which present the same symbol ' $O$ '. The mean difference is significant at the .05 level. 
Considering dependent variables, the results (Table 3) indicate that there was no significant effect of nationality on travel motivation of the French, Spanish and German tourists $(F=.446, p>.05)$.

Table 3 - The Main ANOVA Summary Table of Travel Motivation

\begin{tabular}{|c|c|c|c|c|c|}
\hline & Sum of Squares & df & Mean Square & $\mathbf{F}$ & Sig. \\
\hline Between Groups & .291 & 2 & .145 & .446 & .641 \\
\hline Within Groups & 33.578 & 103 & .326 & & \\
\hline Total & 33.869 & 105 & & & \\
\hline
\end{tabular}

The partial correlation matrix (Table 4) revealed that cultural values were significant relationship with travel motivation, $\mathrm{r}=.409, \mathrm{p}<.001$ and nationality, $\mathrm{r}=.291, p<.01$ while nationality was significantly related to cultural value, except to travel motivation. According to the partial correlation of cultural values and travel motivations which controlled for nationalities, the partial correlation between cultural values and travel motivation is $.445, p<001$, which is considerably similar to the correlation when the effect of nationalities is not controlled for ( $\mathrm{r}$ $=.409$ ). This analysis has shown that nationality was no significant relationship with travel motivations.

A correlation was performed to explore the relationship between cultural values and travel motivation (Table 5). The achievement, benevolence, tradition and conformity components were positively correlated with the both push and pull motivation, the stimulation, self-direction and universalism components were positively correlated with push motivation whereas security component was positively correlated with pull motivation.

Table 4 - Partial Correlation Coefficients of Cultural Values, Travel Motivations and Nationalities of the Tourists

\begin{tabular}{clccccc}
\hline \multirow{2}{*}{ Variables } & \multicolumn{3}{c}{ Zero Order Partials } & \multicolumn{2}{c}{ Controlling for nationalities } \\
\cline { 2 - 6 } & & CVMEAN & TMMEAN & NATION & CVMEAN & TMMEAN \\
\hline CVMEAN & Person Correlation & 1.0000 & $.409 * *$ & $.291 * *$ & 1.0000 & .445 \\
& Sig. (2-tailed) &. & .000 & .002 & .000 & .445 \\
TMMEAN & Person Correlation & $.409 * *$ & 1.0000 & -.056 & .000 & .000 \\
& Sig. (2-tailed) & .000 & $.291 * *$ & -.056 & 1.0000 &. \\
NATION & Person Correlation & .002 & .572 &. & \\
& Sig. (2-tailed) & &
\end{tabular}

**. Correlation is significant at the 0.01 level (2-tailed)

Table 5 - Correlations Between the Cultural Values components and Travel Motivation of the tourists

\begin{tabular}{lll}
\hline \multicolumn{1}{c}{ Cultural Values } & Push & Pull \\
\hline Achievement & $.267^{* *}$ & $.249^{*}$ \\
Stimulation & $.418^{* *}$ & .187 \\
Self-Direction & $.245^{*}$ & .138 \\
Universalism & $.251^{* *}$ & .179 \\
Benevolence & $.361^{* *}$ & $.215^{*}$ \\
Tradition & $.323^{* *}$ & $.324^{* *}$ \\
Conformity & $.311^{* *}$ & $.270^{* *}$ \\
Security & .136 & $.243^{*}$ \\
\hline
\end{tabular}

**. Correlation is significant at the 0.01 level (2-tailed)

*. Correlation id significant at the 0.05 level (2-tailed)

\section{DISCUSSION OF THE FINDING BY RESEARCH QUESTIONS}

The results of our research question reveal that demographic characteristic produce cultural values while cultural value reflected travel motivation.

The findings from the research questions were as follows:

\section{Cultural values of French, Spanish, and German tourists}

The first research question attempted to examine the differences and similarities of cultural values in three nationalities - French, Spanish and German. 
1. The overall findings indicated that out of the 10 cultural values, only a set of the five cultural values was shared similarly in term of power, achievement, hedonism, stimulation, and tradition. On the other hand, a constellation of five of cultural values was different in term of self-direction, universalism, benevolence, conformity and security.

2. The French and German differed from Spanish in term of self-direction, universalism and benevolence.

3. The French, Spanish and German differed in term of conformity and security.

4. French, Spanish and German shared the same cultural value priority in the highest and the last two lowest priorities. The highest shared cultural value was universalism while tradition and power were shared as the lowest priorities of cultural values among the three nationalities.

5. German reveals the greater degree of all cultural values compared with French and Spanish.

6. Spanish nationality revels the similar pattern to both French and German in eight terms of cultural values.

\section{Travel motivation of French, Spanish and German tourists}

The research question 2 attempted to examine the difference and similarity pattern of travel motivation of the three nations.

1. There was no significant difference in pattern of the travel motivation among the three nationalities. The French, Spanish and German tourists exhibit the similarities in terms of push and pull motivation.

2. German reveals the lowest degree of all travel motivations which in cultural value reveals the highest in all terms.

The relationship among nationality, cultural values and travel motivations

The research question 3 attempted to extent the research question 2 to examine the influence variable to travel motivation by finding relationship among nationality, cultural values and travel motivations.

1. The finding shown that nationality was no significant relationship with travel motivations, however the nationality was significantly related to cultural values and cultural values were significantly related to travel motivation. It can be generally assumed that cultural affect travel motivation for travelers; for example, a person who has universalism value as the first priority guide in their life may focus on push motivation of travel.

\section{Cultural values influence the travel motivations}

The research question 4 attempted to extent the research question 3 to examine the how cultural values influence travel motivations of the tourists.

The principal component analysis extracted eight cultural values influenced the travel motivation. The achievement, benevolence, tradition and conformity components were significantly related to both push and pull motivations. The stimulation, self-direction and universalism components were significantly related to only push motivation while security component was significantly related to only pull motivation.

\section{The relationship between demographic characteristic and cultural values}

The research question 5 attempted to examine the further variables which influence cultural values. The finding reveals that all gender, age, status and education were no significant relationship with cultural values.

\section{The influence of third-variable to the correlated variable of the cultural values and travel motivations.}

The research question 6 attempted to examine the third-variable that influence the correlated variable of the cultural values and travel motivations. The finding reveal that age of the tourists has discovered a complex relationship between the cultural values and travel motivations. 


\section{CONCLUSIONS}

This study was developed to discover the relationship among demographic characteristics, cultural values and travel motivations of tourists. The major research findings of the questionnaire investigation are as follows: coming from different nationalities, French, Spanish and German exhibit some significant differences and similarity in their cultural values supports Reisinger and Turner (1999) finding that there are cultural differences between populations from difference nation and having different cultural values reflect some significant differences in their travel motivation. Tourist motivations have causal relationships with cultural values. The motivations divide these motivations into push and pull concepts, and shows evidence for each motivation was influenced by cultural values.

Given that French, Spanish and German shared similar the pattern and priority of cultural values agree with Linder's model which suggests that the more similar the demand preferences for manufactured. Tourism marketers should capitalize on this variable when promoting country tourism product to the main and target tourists.

The identification of specific markets can provide competitive advantage was essential to suggest a repositioning strategy to the target tourists from the difference of cultural values. This result emphasizes the importance of acknowledging the relationship between tourist's characteristic, cultural values and travel motivation as the three variables, when combined together, can provide strong attributes that could be used in the development of the tourism strategy.

\section{AUTHOR' INFORMATION}

Acheraporn Plangmarn resides in Lampang, Thailand. She is a lecturer in the Department of Business Administration, Rajamangala University of Technology Lanna. She received a Bachelor of Business Administration degree in Marketing from Yonok College, a Master of Business Administration in Marketing from ChiangMai

University and she is currently studying in the Doctoral Business Administration program at the Institute of International Studies, Ramkhamhaeng University. E-mail: acheraporn@gmail.com (Corresponding author)

Bahaudin G. Mujtaba is Professor of Management, Human Resources and International Management at Nova Southeastern University's the H. Wayne Huizenga School of Business and Entrepreneurship in Fort Lauderdale, Florida, United States of America. His areas of research interests include quality improvement, customer service, employee retention, employee commitment, diversity management, and cross-cultural management practices. E-mail: Mujtaba@nova.edu

Mohammed Pirani is Professor of Business at The Institute of International Studies, Bangkok. Prior to that he taught at the Liverpool John Moores University, UK. His research publications range from Earnings Inequality, Education and Human Resource management. E-mail: m.pirani@sky.com

\section{REFERENCE}

1. Baloglu, S. (1997), "The relationship between destination images and socio-Demographic and trip characteristics of international travelers", Journal of Vacation Marketing, Vol. 3, pp. 221-33.

2. Baloglu, S. and McCleary, K. (1999), “A model of destination image formation”, Annals Of Tourism Research, Vol. 26 No. 4, pp. 868-97.

3. Beerli, A. and Martı'n, J.D. (2004), "Factors influencing destination image", Annals Of Tourism Research, Vol. 31, pp. 657-81.

4. Bello, D.C., \& Etzel, M.J. (1985). The rate of novelty in pleasure travel experiences. Journal of Travel Research, 24(1), 20-26.

5. Correia, A. and Crouch, G. (2004), "A study of tourist decision processes: Algarve, Portugal”, in Crouch, G., Perdue, R., Timmermans, H. and Uysal, M. (Eds), Consumer Psychology of Tourism, Hospitality and Leisure, Vol. 3, CABI Publishing, Wallingford.

6. Correia, A., Barros, C. and Silvestre, A. (2007a), "Tourism golf repeat choice behavior in The Algarve, a mixed logit approach", Tourism Economics, Vol. 13 No. 1, pp. 111-27. 
7. Crompton, J. (1979), "Motivations for pleasure vacations", Annals of Tourism Research, Vol. 6 No. 4, pp. 408-24.

8. Dann, G. (1981), "Tourist motivation - an appraisal”, Annals of Tourism Research, Vol. 8 No. 2, pp. 187219.

9. Dann, G. (1996), “Tourists' images of a destination - an alternative analysis", Recent Advances and Tourism Marketing Research, Vol. 5 Nos 1/2, pp. 41-55.

10. $\quad$ Engel, J.F. and Blackwell, R.D. (1982), Consumer Behavior, 4th ed., Dryden, Chicago, IL.

11. Fayed, H., \& Fletcher, J. (2002). Globalization of economic activity: Issues for tourism.

12. Fodness, D. (1994), "Measuring tourist motivation", Annals of Tourism Research, Vol. 21 No. 3, pp. 55581.

13. Friedman, J. (1995). Global system, globalization and the parameters of modernity. Global modernities, Featherstone, M. (Ed.), Sage, London.

14. Gartner, W. (1993), "Image formation process", in Uysal, M. and Fesenmaier, D. (Eds), Communication and Channel Systems in Tourism Marketing, Haworth Press, New York, NY, pp. 191-215.

15. Gnoth, J. (1997), "Tourism motivation and expectation formation", Annals of Tourism Research, Vol. 24 No. 2, pp. 283-304.

16. Hofstede, G. (1991), Cultures and Organizations: Software of the Mind, McGraw-Hill, London.

17. Hofstede, G. (2001). Culture's consequences: Comparing values, behaviors, institutions, and organizations across nations, (2nd ed.). Sage Publications, Thousand Oaks.

18. Inglehart, R. (1997), Modernization and Post-modernization: Cultural, Economic and Political Change in 43 Societies, Princeton University Press, Princeton, NJ.

19. Iso-Ahola, S. and Mannel, R. (1987), "Psychological nature of leisure and tourism experience", Annals of Tourism Research, Vol. 14 No. 3, pp. 314-31.

20. Keegan, W.J. (1984), Multinational marketing management, 3rd ed., Prentice-Hall, New York, NY.

21. Kluckhohn, C. (1951), "The study of culture", in Lerner, D. and Lasswell, H.D. (Eds), The Policy Sciences, Stanford University Press, Stanford, CA, pp. 86-101.

22. Kroeber, L., \& Kluckhohn, C. (1952). Culture: A critical review of concepts and definitions. Papers of the Peabody Museum of American Archaeology and Ethnology, Harvard University Press 47(1): 223. New York Random House.

23. Lundberg (1990), The Tourist Business, 6th ed., van Nostrand Reinhold, New York, NY.

24. Malinowski, B. (1988). Eine wissenschaftliche Theorie Der Kultur, (3rd ed.). Suhrkamp, Frankfurt/Main.

25. Mohsin, A. and Ryan, C. (2003), "Backpackers in the northern territory of Australia", The International Journal of Tourism Research, Vol. 5 No. 2, pp. 113-21.

26. Otaki, M., Durrett, M.E., Richards, P., Nyquist, L. and Pennebaker, J. (1986), “'Maternal and infant behavior in Japan and America", Journal of Cross-Cultural Psychology, Vol. 17 No. 3, pp. 251-68.

27. Pearce, P. (1982), "Perceived changes in holiday destinations", Annals of Tourism Research, Vol. 9 No. 2, pp. 145-64.

28. Pizam, A. and Reichel, A. (1996), 'The effect of nationality on tourist behavior: Israeli tour-guides' perceptions", Journal of Hospitality and Leisure Marketing, Vol. 4 No. 1, pp. 23-49.

29. Pizam, A. and Sussman, S. (1995), "Does nationality effect tourist behavior?", Annals of Tourism Research, Vol. 22 No. 2, pp. 901-17.

30. Pizam, A., Neumann, Y., \& Reichel, A. (1979). Tourist satisfaction, Annals of Tourism Research, 6, 195197.

31. Pizam, A., Pine, R., Mok, C. and Shin, J.Y. (1997), “Nationality versus industry cultures: which has greater effect on managerial behavior?", International Journal of Hospitality Management, Vol. 16 No. 2, pp. 127-45. Ralston, D.A., Egri, C.A., Stewart, S.,

32. Reisinger, Y., and L. Turner (1999). "A Cultural Analysis of Japanese Tourists: Challenges for Tourism Marketers." European Journal of Marketing, 33 (11/12): 1203-27.

33. Rokeach, M. (1973). Understanding human values: Individual and societal, New York: Free Press.

34. Sagiv, L. and Schwartz, S.H. (2000), 'A new look at national culture: illustrative applications to role stress and managerial behavior', in Ashkanasy, N.N., Wilderom, C. and Peterson, M.F. (Eds.): The Handbook of Organizational Culture and Climate, Sage, Newbury Park, CA, pp.417-436. 
35. Schwartz, S.H. (1994), "Beyond individualism/collectivism: new cultural dimensions of values", in Kim, U., Triandis, H.C., Kagitcibasi, Cigdem, Choi, S.-C., and Yoon, G. (Eds), Individualism and Collectivism: Theory, Methods and Applications, Sage, London, pp. 85-119.

36. Schwartz, S.H. (1999), "A theory of cultural values and some implications for work", Applied Psychology: An International Review, Vol. 48, pp. 23-47.

37. Schwartz, S.H. (2004) 'Mapping and interpreting cultural differences around the world', in Vinken, H., Soeters, J. and Ester, P. (Eds.): Comparing Cultures, Dimensions of Culture in a Comparative Perspective, Brill, Leiden, The Netherlands, pp.43-73.

38. Schwartz, S.H. and Bardi, A. (2001), "Value hierarchies across cultures: taking a Similarities perspective", Journal of Cross-Cultural Psychology, Vol. 32, pp. 268-90.

39. Schwartz, S.H.(1992): Universals in the content and structure of values: theoretical advances and empirical tests in 20 countries In: Zanna,M. (ed.) Advances in Experimental Social Psychology, vol. 25, pp. 1-65. Academic Press, Orlando

40. Shoemaker, S. (1989), "Segmentation of the senior pleasure travel market", Journal Of Travel Research, Vol. 27 No. 3, pp. 14-21.

41. Svanberg, I., \& Runblom, H. (1988). Det margkulturella Sverige. En hundbok om Etniska grupper och minoriteter. The multicultural Sweden. A handbook on ethn

42. Trice, H.M. and Beyer, J.M. (1993) The Cultures of Work Organizations, Prentice-Hall, Englewood Cliffs, NJ.

43. Usinier, J.C. (1993), International Marketing: A Cultural Approach, Prentice-Hall, New York, NY.

44. Uysal, M., \& Jurowski, C. (1993). An empirical testing of the push and pull factors of tourist motivations. Annals of Tourism Research, 21(4), 844-846.

45. Uysal, M., and Hagan, L. (1993). Motivations for pleasure travel and tourism. In M. Khan, M. Olsen, \& T. Var (Eds.), Encyclopedia of hospitality and tourism (pp. 798-810). New York: Van Nostrand Reinhold.

46. Uysal, M., Mclellan, R. and Syrakaya, E. (1996), "Modelling vacation destination decisions: a behavioral approach", Recent Advances in Tourism Marketing Research, Vol. 5 Nos 1/2, pp. 57-75.

47. Weiermair, K. (2000), "Tourists' perceptions towards and satisfaction with service quality in the crosscultural service encounter: implications for hospitality and tourism management", Management Service Quality, Vol. 10 No. 6, pp. 397-409.

48. Williams, R. M. (1970). American society. A sociological interpretation, (3rd ed.). Knopf, New York.

49. Woodside, A.G., Krauss, E., Caldwell, M. and Chebat, J. (2007), "AAdvancing theory for Understanding travelers' own explanations of discretionary travel behavior", Journal of Travel and Tourism Marketing, Vol. 22 No. 1, pp. 15-35.

50. Yoon, Y. and Uysal, M. (2005), "An examination of the effects of motivation and satisfaction on destination loyalty: a structural model”, Tourism Management, Vol. 26 No. 1, pp. 45-56. 